\title{
Las incertidumbres del corazón: la Historia y el mundo de los afectos ${ }^{1}$
}

\author{
María José de la Pascua SÁnchez \\ Universidad de Cádiz \\ mariajose.pascua@uca.es
}

Fecha de recepción: 12/05/2015

Fecha de aceptación: 02/07/2015

\section{RESUMEN}

En este artículo, ensayo una metodología para acercar la historia de las emociones a la vivencia del amor, a partir del análisis de fuentes de diversa procedencia, (epitalamios, obras espirituales y filosóficas, novela cortesana y sentimental, expedientes inquisitoriales, cartas) que constituyen depósitos de la praxis discursiva de la cultura amorosa de los siglos XV al XVIII. Paralelamente se propone un análisis de las prácticas de amor que tenga en cuenta la especificidad del sentido del tiempo en las vivencias emocionales y el contexto de la vida cotidiana que les otorgan sentido y significado.

Palabras clave: Historia social, Historia de las emociones, Historia de la vida cotidiana, Historia moderna, amor y matrimonio, fuentes y metodología para una historia de los afectos, epitalamios.

\section{Uncertainties of the Heart: The History and the World of Emotions}

\begin{abstract}
In this article I use a methodology to bring history's emotions closer to the experience of love from the analysis of diverse sources (epithalamios, spiritual and philosophical works, courtesan and sentimental novels, inquisitorial records, letters) that constitute deposits of discursive praxis of loving culture of the Fifteenth to Eighteenth Centuries. It also suggest a parallel analysis of the love practices that takes into account the specificity the sense of time in emotional experiences and the context of daily life that gives them meaning and significance.
\end{abstract}

Key words: Social History, History's Emotions, Early Modern History, Love and Marriage, Sources and Methods for a History of Emotions, Epithalamios.

\footnotetext{
1 Investigación en el marco del Proyecto HAR2014-53802-P, financiado por el Ministerio de Economía y Competitividad.
} 
Empezaré por justificar el título del artículo. Un título que tiene historia como la materia que nos ocupa -el amor-. Viene sugerido por aquel otro (Las intermitencias del corazón $)^{2}$ que Marcel Proust eligió para el conjunto de su obra denominada finalmente, ante la coincidencia en la publicación de otra novela contemporánea ( $L e$ coeur en désordre de Binet-Valmer), À la recherche du temps perdu y que se abriría con la edición de la novela Du côté de chez Swan (1913). En busca del tiempo perdi$d o$ es un título muy apto para esas siete novelas que constituyen una obra hija de la obsesión del autor por la dimensión subjetiva de la existencia humana, pero también las intermitencias del corazón como la identificaría originalmente Proust habría sido una buena elección, puesto que en la vivencia del amor, o de los afectos, la cualidad temporal se manifiesta de forma muy particular y compleja. Proust recala con insistencia, una y otra vez, en la complejidad del mundo afectivo y de las construcciones que los humanos hacemos sobre el amor y en ellas el tiempo se yergue como variable determinante. En los amores que se pierden, en los que permanecen, en los incondicionales, en los volubles, en los divertidos, en los inconvenientes, en los prohibidos $\mathrm{y}$, especialmente en aquellos que crecen al amparo de los juegos de la imaginación, en todos ellos, el paso del tiempo se hace visible en las incertidumbres del que ama, en la rápida transformación de lo que se desea una vez conseguido, en la huella de la ausencia o de la traición.

Pero, a diferencia de lo que pudiera sugerir el título común de estas siete novelas, À la recherche du temps perdu, no es sólo lo efímero de la vida y los afectos lo que la obra de Proust plantea y por lo que recurro a ella. Hay dos aspectos más que en una perspectiva de la historia de los afectos merecen ser destacados. Para Proust, su novela trata de la memoria, pero no de aquella que se construye con la lógica racional de la ciencia: esa dice el autor "no nos da el pasado sino caras desprovistas de verdad"3, frente a ella él persigue la memoria involuntaria de lo cotidiano: un olor, un sabor, un paisaje o una imagen que traen hasta el presente un pasado que nos emociona con el hechizo, la verdad y la solidez de lo auténtico. Como historiadores tendríamos mucho que pensar y debatir sobre estas dos formas de atrapar el tiempo que, en mi opinión, no están tan enfrentadas como sugiere Proust. Pero es cierto que, para el historiador, adentrarse por esas memorias involuntarias de lo cotidiano, olvidadas en las fuentes por su debilidad existencial, su nadería, o por la sospecha de subjetividad que ha llevado durante mucho tiempo a despreciarlas, es un camino mucho más seguro de reconstrucción de los afectos como trataré de explicar más adelante. Sólo de los recuerdos involuntarios se extrae materia prima para la obra -afirma Proust- , para la del novelista, obviamente, pero también para el historiador del amor. Aún hay una realidad más de la obra de Proust que da que pensar. Esa obra que algunos no entendieron cuando empezaba a publicarse desconcertados con tantas páginas dedicadas a lo que aparentemente no es novelable, no puede-debe ser narrado, no es una gesta, no es una epopeya, no tiene desarrollo..., y, en definitiva, no da estructura a una novela concebida como épica sentimental y holística. Según esta opinión, la ansiedad, el

\footnotetext{
2 DE DIESBACH, G.: Marcel Proust, Barcelona, Anagrama, 2013, p. 418 y 426.

3 Entrevista de Élie-Joseph Bois a Marcel Proust, publicada en Le Temps en noviembre de 1913, Ibidem, p. 433 .
} 
dolor, la angustia, la pérdida, la soledad, el desamparo, en fin, aquello que construye el mundo de las emociones y los sentimientos..., es materia despreciable de la vida de los seres humanos, al menos cuando se trata de los individuos anónimos y así se ha considerado durante décadas de novela y de historia.

¿Por qué esta reflexión sobre el fluir del tiempo, los recuerdos involuntarios o las emociones cotidianas contenidas en palabras y hechos banales? Porque estos temas serán nuestras referencias para construcción de una historia de los afectos. Aunque antes es preciso revisar algunas de las opiniones comunes que durante mucho tiempo han impedido una historia del amor. En primer lugar la opinión generalizada de que el amor no tiene historia, no cambia con el tiempo, es un universal que todos los humanos, hombres o mujeres, han sentido desde tiempo inmemorial desde las mismas premisas y con las mismas claves. En segundo lugar, porque una vez abandonada esta postura, en líneas generales en la historiografía de finales de los setenta, los historiadores nos instalamos habitualmente en una concepción del amor esencialista, desde un modelo, el del amor romántico y desde la idea de que es una emoción primera, primitiva y no contaminada por ninguna otra emoción ni por ningún interés material. Cuando, en realidad, la vivencia del amor va asociada al resto de las vivencias, se halla inmersa en la propia vida y en las circunstancias personales de cada uno. En este sentido para su historia no son tan útiles las declaraciones sobre lo que se opina del amor, los bellos discursos de palabras grandes elaborados voluntariamente para que sean oídos y recordados, como esos otros pequeños recuerdos involuntarios evocados a través de la música o una canción, y que llevan a un individuo a recrear más que un hecho, una circunstancia, una situación vivida y de paso a vivir una nueva emoción. Rastrear esos recuerdos, esas percepciones a través de la abundante documentación indirecta a la que podemos acceder nos situará a este nivel del tiempo recobrado involuntariamente del que se habla en la Recherche proustiana. Un apunte aclaratorio más en relación con el espacio de lo cotidiano imaginado, muchas veces, por los historiadores como un territorio pequeño de la Historia, sin percibir que, en la vida de las personas y, por lo tanto en la Historia, cada hecho, cada experiencia se halla siempre contextualizado. A ello remite el paradigma de la acción situada que tiende hoy a sustituir, en la historia social, al clásico enfoque estructuralista desde una perspectiva sociológica interpretativa que valora el papel del individuo en la construcción de su mundo social, pero también el sentido común que nos avisa que no hay compartimentos estancos, ni líneas fronterizas que separen lo trivial de lo importante, lo excepcional de lo cotidiano.

\section{AMOR Y PLACER EN LA CULTURA AMOROSA DE LA EDAD MODERNA}

El punto de partida de esta historia es el amor como producto cultural elaborado a partir de, como algo distinto/diferenciado, del instinto sexual animal, y por tanto humano, personal-individual y, al tiempo, cultural. En esa transformación del impulso reproductor animal en una representación, el amor se construye mediante un proceso simbiótico de ritualización y sublimación de la mano de la cultura amorosa en la que el sujeto vive, que, como tal, es histórica. Así, aunque la imagen del amor aparezca 
sin cambios sustanciales desde el siglo XII -modelo de amor cortés- hasta hoy, hay cambios que el historiador debe explicar y relacionar con los procesos sociales que le sirven de contexto. El individuo navega por las incertidumbres del corazón adherido a su cultura y a su propio tiempo. Por ello uno de los estadios de análisis necesarios es la inmersión en la cultura amorosa de la época; sin este análisis difícilmente podemos interpretar las prácticas individuales o de grupo. No es conveniente pues, acercarse a estas últimas como si fuesen, exclusivamente, el producto de un "no sé qué primario e inexplicable"; las emociones como productos culturales que son se hallan relacionadas con las creencias. El amor lo es también y, tanto para su vivencia como para explicarlo, necesitamos claves temporales, los recursos retóricos de cada tiempo con los que los individuos traducen e interpretan lo que viven y sienten. Al respecto hay un supuesto que los historiadores modernistas debemos empezar a matizar y es aquel según el cual en la edad moderna el amor no existía como valor social significante y que la cultura amorosa se resolvía, básicamente, de forma reiterativa y simplista, en la contradicción entre amor honesto y amor pasional. Los matrimonios, se repite con frecuencia, no eran un asunto de amor. No hay duda de la importancia del matrimonio como estrategia política, ni de la práctica muy difundida en estos siglos por todo el espectro social de concertar alianzas matrimoniales de acuerdo con los intereses familiares. Matrimonios pactados, a veces incluso contemplando varias alianzas matrimoniales entre las dos familias implicadas, como sucedía en los llamados matrimonios a trueque. Pero la existencia de estos conciertos matrimoniales, exceptuando los matrimonios dinásticos con motivaciones de índole muy específicas ${ }^{4}$, no implicaba tanto una exclusión del amor como valor recomendable en la pareja, cuanto una concepción del mismo acorde con los valores de la época, dentro de los intereses del grupo social o familia de procedencia y en la perspectiva orientadora de un concepto importante dentro del discurso culto del momento, la amicitia entre iguales ${ }^{5}$, aquel afecto que surge entre personas con la misma formación, valores, e intereses. En este sentido, el recurso a las fuentes permite matizar y explicar mejor esos rasgos implicados en aquella cultura amorosa. Dejemos hablar a los autores a través de tratados de amor y algunas obras morales y filosóficas famosas en estos siglos

Tomemos un célebre libro del XVI, El Tercer Abecedario de Francisco de Osuna; espiritualidad al alcance de los sencillos en un ambiente español de reforma cisneriana pero también en un contexto de irrupción del protestantismo y de aparición del alumbradismo. Un libro publicado en Toledo en 1527. Podríamos elegir otros libros que hablaban de amor: el Cántico Espiritual (1577) de san Juan de la Cruz, los Conceptos del amor a Dios (h. 1575) de Teresa de Jesús, ambos con un lenguaje apasionado, la segunda ejecutando un paso casi obligado en la literatura ascético mística, la glosa de algunos versos de la canción nupcial por excelencia, el Cantar de los Cantares. Lo podríamos hacer porque en el siglo largo que va entre 1540 y 1680 es posible rastrear medio centenar de títulos que tratan del amor publicados en los

4 BENNASSAR, B.: Reinas y princesas del Renacimiento a la Ilustración. El lecho, el poder y la muerte, Barcelona, Paidós, 2007.

5 HESPANHA, A. M.: "Sabios y rústicos, La dulce violencia de la razón jurídica”, en La gracia del derecho. Economía de la cultura en le Edad Moderna, Madrid, Centro de Estudios Constitucionales, 1993, pp. 17-60. 
reinos de España o escritos por españoles ${ }^{6}$. Pero sigamos con Osuna que en la tercera parte de su Abecedario Espiritual, en un lenguaje lejano del academicismo teológico escolástico se plantea explicar el amor y con el respaldo de una cita de San Bernardo, desglosa sus clases: "Dos amores hay: el uno es carnal y el otro espiritual; de los cuales se cogen cuatro maneras de amar que son amar la carne carnalmente, el espíritu carnalmente, la carne espiritualmente y el espíritu espiritualmente"7.

Parece un galimatías pero no lo es. Osuna advierte de distintas formas de afrontar el deseo del otro y que la carne se puede amar espiritualmente. También al revés. ¿Hay alguna definición mejor del amor que esta según la cual el amor transforma el cuerpo en espíritu y el espíritu en cuerpo? Amar en cuerpo y alma. ¿No rastreamos en esta especie de circunloquio, el camino de sublimación que conduce del apetito sexual al erotismo y del erotismo al amor? ${ }^{8}$. Osuna, sigue con su descripción del amor, y en el capítulo IX vuelve a preguntarse cómo ha de ser y escribe:

Pónense, empero, muchas maneras de amor, de las cuales se podría hacer un libro por sí, ca un amor hay que se dice libre, otro natural, otro gratuito, otro seráfico, otro purgativo, iluminativo, perfectivo, habitual, sobrenatural, extático, fuerte, sabio, dulce, insuperable, insaciable, singular, movible, incesable, cálido, ferviente, penetrativo, agudo, inflexible, recto, intenso, íntimo, franco, unitivo, afectuoso, tierno, espiritual, comunicativo, irremisible, indeclinable, total, infinito... ${ }^{9}$

Y sigue. La ristra de calificativos con el que se caracteriza al amor, nos pone en contacto con distintas formas de amor -afectuoso, iluminativo, habitual-, pero también con diferentes cualidades del amor con las que ya podemos construir una imaginería del amor de la época (insaciable, singular, ferviente, penetrativo, comunicativo, perfectivo, total, infinito) y en la que son identificables algunas constantes del imaginario del amor (exclusividad, libertad, entrega, subversión, alienación, elección) pero también el sesgo que introduce la propia cultura de estos siglos y que se percibe en cualidades como amor operativo, amor desnudo, amor esencial y amor unitivo -las fases del amor místico ${ }^{10}$ - así como en una cierta decantación, muy lógica por otra parte dada la naturaleza del texto, hacia lo espiritual. Aunque en ninguno de estos textos ni en otros textos místicos se conciban la carne y el espíritu como realidades separadas, siendo la mística como es un nuevo lenguaje inscrito en el cuerpo ${ }^{11}$.

6 Se localizan 44 títulos repartidos entre el siglo XVI (12), siglo XVII (23) y siglo XVIII (9); es decir que más de la mitad pertenecen al XVII y las dos terceras partes al periodo comprendido entre 1540 y 1680 . Extraigo los datos del amplio catálogo de libros espirituales de ANDRÉS, M.: Historia de la mística de la Edad de oro en España y América, Madrid, BAC, 1994, pp. 153-207.

7 DE OSUNA, F.: Tercer Abecedario Espiritual, Toledo, 1527, en LÓPEZ, S. (ed.): Místicos franciscanos españoles, Madrid, BAC, 2005, Tomo II, p. 91.

8 Para Octavio PAZ todos los enamorados navegan entre lo espiritual y lo corporal, distinguiendo en un cuerpo los atributos de un alma y al contrario, incurriendo así en una cierta paradoja en La llama doble. Amor y erotismo, Barcelona, Seix-Barral, 1993, p. 130

9 DE OSUNA, op. cit. (nota 7), pp. 446-447.

10 DE LAREDO, fray B.: Subida al Monte Sión, en GOMIS, fray J. B.: Místicos Franciscanos Españoles, Madrid, BAC, 1948, Tomo II, p. 3.

11 "Cuanto más bestias sean los movimientos carnales, más redundarán en nuestro beneficio si los doblegamos" porque, apuntará siguiendo a San Bernardo, "el fuego de la lujuria es martirio prolijo", DE 
Amor descrito con cualidades infinitas que, pueden desbordar la imaginación más poética, amor, en fin, cuya lógica se desbroza en otras obras famosas como la de León Hebreo, Dialoghi di amore, Roma, $1535^{12}$. Obra escrita por un místico judío expatriado en Italia que la escribe en italiano, aunque muy influido por el pensamiento español del XVI. Nacido en Lisboa, criado en Toledo, exiliado en Italia, Hebreo escribe su obra en forma de diálogo, un género que triunfaba el XVI y la estructura en tres diálogos. Hablan Filón y Sofía, que tratan los temas de la relación entre el amor y el deseo (diálogo I), la genealogía del amor (diálogo II) y el amor como camino desde lo exterior al interior del hombre o camino de ensimismamiento (diálogo III). El diálogo asume la forma de debate, al modo platónico, en el que los que hablan mantienen posturas encontradas hasta converger en la conclusión más fundamentada. En el primero Sofía sostiene un lugar común, también argumento frecuente en la voz de las mujeres de la época, a saber, que el deseo y el amor acaban siguiendo caminos contrarios pues el deseo una vez satisfecho hace desaparecer la estima de aquello que se quería. Filón no está de acuerdo con esta posición de Sofía y en su argumentación establece tres tipos de amor (deleitable, provechoso y honesto) en función de la diferencia que, según el autor, existe entre afán de posesión (deseo) y disfrutar con (amor). Uno y otro no deben confundirse y, según Hebreo, el amor (honesto) en esta modalidad de disfrutar con es producto del alma intelectiva y fruto de la virtud y de la sabiduría, aunque no excluye el deleite ${ }^{13}$. El amor matrimonial, apostilla, contiene los tres amores y la unión corporal no priva al amor que es de verdad de amistad y cordialidad sino que lo enlaza más, en cualquier caso, aunque el amor sea hijo del deseo es producto elaborado con la Razón ${ }^{14}$. La no contradicción entre Amor y Razón, bajo la radical interrelación entre ambas, es el aspecto más interesante, a mí entender, del análisis de Hebreo que nos lo presenta como un pensador fiel a un horizonte cultural neoplatónico y compartiendo la idea de un amor omnipresente en el Universo como defenderán Marsilio Ficino y otros humanistas e intelectuales del momento. Sofía vuelve a representar la opinión dominante, expresando que ella pensaba que lo que separaba al amor virtuoso del lascivo era el "desenfrenamiento" y que, tras las palabras de Filón, está desconcertada y no sabe cual es el amor perfecto. De nuevo Filón vuelve a contradecir estas opiniones comunes, explicándole que el desenfrenamiento está en los dos, en el amor honesto y en el lascivo, pero que es un desenfrenamiento dirigido y sometido en el amor honesto y no sometido a la virtud en el amor deshonesto. A modo de conclusión, Filón cierra el diálogo de la misma forma que lo abre, estableciendo el vínculo entre deseo y amor; entendiendo que así como el amor es deseo de unión perfecta con el amado no puede concebirse sino con la penetración perfecta del uno en el otro: comunidad de cuerpos, comunidad de almas.

\footnotetext{
ÁVILA, J. (1556): Avisos y reglas cristianas sobre aquel verso de David Audi Filia (edición no expurgada reeditada por Juan Salas Balust) Barcelona, 1963, pp.19-20. O, en palabras de Osuna: "El mal deseo carnal, que nunca dice basta, sino siempre daca, daca, se puede llamar serpiente que todos pisamos cuando entramos en el mundo, pues que fuimos en él concebidos" (DE OSUNA, op. cit. (nota 7), p. 534).

12 HEBREO, L.: Diálogos de Amor (1535), Buenos Aires- México, Espasa Calpe, 1947 (2ª ed. a partir de la traducción de Inca Garcilaso de la Vega en 1586).

13 Ibidem, pp. 10-28.

14 Ibidem, pp. 54-56.
} 
La genealogía del amor será el tema del II Diálogo donde se comienza por distinguir entre el deseo animal y la atracción amorosa del hombre. Esta última, a diferencia de la primera es, según nuestro autor, atracción por un individuo concreto y centrada en la virtud moral e intelectual de aquel que se constituye en sujeto de amor ${ }^{15}$. El amor aparece, pues, como el fruto de una elección personal relacionada con la actividad intelectual -del que ama- y con la virtud, con la del amante en esa búsqueda de un individuo para amar y con la de la persona amada que enamora por virtuosa.

Pero además de estas y otras obras místicas y filosóficas, el vínculo entre amor y deseo es el motivo específico de un género al que los historiadores no hemos concedido la atención que merece, a pesar de su utilidad para el análisis de la relación entre discursos y prácticas y su condición de depósito de lugares comunes sobre el matrimonio y el deseo sexual en la Alta modernidad ${ }^{16}$. Se trata del Epitalamio o canto nupcial, modalidad de poema de circunstancias que en el proceso de adaptación de los géneros del elogio clásico que conoció la Europa moderna, encontró amplia difusión durante los siglos XV al XVII. Cientos de oraciones nupciales compuestas en estos siglos, en general de carácter breve y formulario, muchas de ellas no impresas, ofrecen un buen elenco de figuras de la cultura amorosa de la época entre las que no faltan abundantes imágenes codificadas de la sensualidad, como han destacado algunos de sus estudiosos, en su mayoría del campo de la literatura y de los estudios latinos ${ }^{17}$. Originariamente, en la cultura griega, consistía en un canto de bodas entonado a la puerta de la habitación de los novios por coros de jóvenes, práctica que dará lugar a un género nacido de la conjunción entre estos cantos populares, recogidos por Homero en la Iliada y los cantos nupciales de los poetas griegos. Su tradición pasará al mundo romano y más tarde adquiere una fuerte presencia en la Italia de los siglos XV y XVI, impulsada por el éxito de algunos de sus cultivadores y tratadistas más destacados (Cátulo, Estacio, Pontano, Pseudo-Dionisio de Halicarnaso o Menándro el Rétor). En su mayoría son epitalamios cortesanos, entonados en las bodas de personajes destacados y nobles, lo que no fue obstáculo para una reconocida popularidad. La tradición clásica fijó su estructura y también los temas recurrentes. Respecto a estos últimos, tras el llamamiento a Himeneo, se encadenarán los temas de la alabanza de los novios (linaje, belleza), los juegos eróticos (ardor del novio/miedo de la novia) y el tema de la descendencia. Su presencia, significativa en la literatura española de los siglos XVI y XVII halla uno de sus ejemplos más destacados en el epitalamio de la primera Soledad de Góngora que, no obstante seguir el modelo de la preceptiva clásica, innova anudando elementos del epitalamio cortesano con los de los cantos

15 Ibidem, pp. 63-157.

16 En uno de los destacados análisis que contamos sobre el género (D'ELIA, A. F.: “Marriage, Sexual Pleasure and Learned Brides in the Wedding Orations of Fifteenth-Century Italy", Renaissance Quarterly, 55, n ${ }^{\circ} 2$ (2002), pp. 379-433), se alude precisamente a esta condición de depósito de lugares comunes para fundamentar su valor como fuente de cara a revelar lo que los humanistas del XV consideraban apropiado respecto al matrimonio y lo que sus audiencias esperaban oír en estas canciones de celebración (Ibidem, p. 379).

17 SERRANO, A.: "La novia remisa y el novio ardiente en el epitalamio latino: una imagen que pervive en el Renacimiento", Cuadernos de Filología clásica. Estudios Latinos 23 (2003), pp. 153-170. PONCE, J.: "Eros nupcial: imágenes de la sensualidad en la poesía epitalámica europea", eHumanistica, 15 (2010), pp. 176-208. 
nupciales del mundo real ${ }^{18}$. Desde un primer momento, dentro de la tradición de los epitalamios se diferencian los cantos de bodas que tienen lugar en las bodas anónimas y los cantos nupciales que, en verso o en forma narrativa, se escriben con ocasión de la celebración de una boda ilustre ${ }^{19}$; son estos epitalamios cortesanos los que han llegado hasta nosotros de forma manuscrita o impresa aunque quedan suficientes indicios de los primeros en los diccionarios de la época ${ }^{20}$ y en algunas obras literarias del siglo de Oro, especialmente en las de Lope de Vega ${ }^{21}$. En los reinos hispánicos se escribieron epitalamios para las bodas de Felipe II con Isabel de Valois $(1560)^{22}$ y Ana de Austria (1570) ${ }^{23}$ y algunos otros de celebración de bodas ilustres que han sido objeto de edición crítica y estudio siempre desde la perspectiva de los estudios humanísticos y literarios ${ }^{24}$. Los lugares comunes del género estaban bien establecidos pero no todos los topoi se utilizaron con la misma frecuencia. La invocación a Himeneo, el dios de los matrimonios ${ }^{25}$, el elogio de los novios y de su linaje y la referencia a la futura descendencia son temas casi obligatorios según $M$. Tanabe que, sin embargo, echa en falta en algunos de estos textos el "discurso del lecho nupcial" ${ }^{26}$. Este, no obstante se halla presente en los epitalamios con motivo de las bodas reales de Felipe II con Ana de Austria $^{27}$, donde no falta la referencia al goce sexual. Es justamente este aspecto el que me interesa subrayar en el marco del tema que me ocupa porque

18 TANABE, M.: “Tradición e innovación en el epitalamio de la primera Soledad”, AnMal Electrónica 30 (2011), pp. 59-89.

19 Para los siglos XV y XVI del conjunto de los epitalamios latinos A. Serrano distingue entre los literarios fruto de un ejercicio poético que no responde a una boda real, los familiares destinados a celebrar la boda y los cortesanos cuya finalidad es el panegírico de un personaje influyente con el pretexto de una boda, SERRANO, A.: "Las lágrimas de la noua nupta en la tradición del epitalamio latino", Minerva 24 (2011), pp. 137-155, p. 144.

20 Epithalamio: "El cantar o himno que se dezía en las bodas en honor a los novios; que oy día se usa en las aldeas de Castilla la Vieja, donde yo he oydo muchos...", DE COBARRUVIAS, S.: Tesoro de la lengua Castellana o Española (1611), Madrid, Turner, 1979, p. 528; el Diccionario de Autoridades (1732), recoge la acepción de Cobarruvias. Madrid, Gredos, 1984, t. III, p. 538.

21 La crítica subraya que al menos en 10 obras de Lope se recogen estos cantos de boda y que la mayoría de estas canciones está recogida de la realidad (TANABE, op. cit. (nota 18), p. 82). En Vega, en el valle de Cayón, lugar de nacimiento del padre de Lope de Vega y en otros del entorno de la comarca del Pisueña (Cantabria) se podían oír hasta no hace mucho estas canciones de boda.

22 Diego de Guevara, Epithalamium Philippi et Isabelis Hispaniarum regnum, Alcalá de Henares, J. Brocar, 1560, hay estudio de SERRANO, A.: "El epitalamio latino (1560) de Diego de Guevara en honor de Felipe II e Isabel de Valois", Calamus Renascens, 9 (2008), pp. 245-292 e "Isabel de Valois como esperanza de paz contra la herejía. Motivos del epitalamio en la Oratio cristiana (1560) de Pedro del Frago", Cuadernos de Filología clásica. Estudios Latinos 31, n 2 (2011), pp. 311-331.

23 SERRANO, A.: "El Epithalamium de Jerónimo Ramírez en honor de la boda (1570) de Felipe II y Ana de Austria", Humanistica Lovaniensia: Journal of neo-Latin Studies (2009), pp. 103- 104.

24 La Canción al duque de Pastrana sobre su casamiento (1584) por Juan Rufo, los tres epitalamios que se contienen en Discursos, epístolas y epigramas de Artemidoro de Andrés Rey de Artieda (1605) con motivo de las bodas del duque de Alburquerque, del marqués de La Bañeza y doña María de la Cueva y del marqués de Cuellar y el Epitalamio a doña María Clemente y Enríquez que casó con don Juan de Villalpando (1608), de Lupercio Leonardo de Argensola, vid. TANABE, op. cit. (nota 18), pp. 76-81.

25 Bajo la voz Hymeneo, el Diccionario de Autoridades (1732), destaca su acepción de boda o casamiento más utilizada en lo poético y "que viene de que los antiguos fingían que el Dios Hymeneo asistía a las bodas con un hacha, invocándosele en los epithalamios para que hiciese feliz el casamiento", op. cit., Tomo IV, p. 325 .

26 Ibidem, p. 80.

27 SERRANO, op. cit. (nota 23), 107-108 y op. cit. (nota 17), 153-170 
contradice la imagen plana que exhibimos con cierta reiteración sobre unas supuestas estrategias matrimoniales de las que están ausentes los argumentos no relacionados con la política, la riqueza o el estatus. En este sentido Anthony F. D'Elia en su estudio sobre un nutrido grupo de oraciones nupciales de la Italia del Quinientos, testimonios de la reanimación del género en las cortes de Ferrara, Nápoles, Milán entre otras, insiste en señalar su importancia entre los elementos que van a transformar las bodas en un acontecimiento festivo de notable magnificencia y trascendencia. También en su condición de fuente que ofrece al estudioso una pintura viva de los ideales matrimoniales cortesanos de la Italia del Quinientos; pintura mucho más compleja de la que suele trazarse y en la que los argumentos sobre la importancia del linaje y la riqueza en la concertación de un matrimonio no excluyen aquellos otros sobre la alegría de la dulce compañía y el placer del goce sexual ${ }^{28}$. Una retórica que, según apostilla el referido autor, vincula más esta concepción del matrimonio con la tradición pagana clásica que con el espíritu ascético y la tradición cristiana ${ }^{29}$.

La vivencia del amor representada como un diálogo, no siempre pacífico, entre la castidad y el placer, ni fue tema ajeno a la iconografía de la época, ni tampoco al argumentario de los poetas que cantaban al matrimonio en las cortes europeas entre los siglos XV y XVIII. La interpenetración de figuras, símbolos y temas en la literatura, la iconografía ${ }^{30}$ y estas canciones nupciales es suficientemente elocuente de la capacidad de circulación de estos materiales en la conformación de la cultura amorosa de la época. Por mi parte me detendré en el análisis de dos epitalamios localizados en el Archivo Histórico Nacional. Se trata del Epitalamio a las felices bodas de los excelentísimos señores marqueses de Villena, de Francisco Manuel Therán, archivero de la Casa y Estados del Ducado de Uceda (1764) ${ }^{31}$ y del que la ciudad de Béjar encarga con motivo de la boda de los marqueses de Peñafiel en $1803^{32}$. El primero de ellos responde al modelo de epitalamio cortesano tanto en la forma como en el fondo. Tras las dedicatorias a los novios y a sus padres, los duques de Uceda, y de la obligada petición de benevolencia al lector, el autor se justifica como poeta de esta canción nupcial aludiendo a su doble condición de vasallo incondicional del

28 D'ELIA, op. cit. (nota 16), p. 380.

29 Ibidem, pp. 421-422, y D'ELIA, A. F.: The Renaissance of Marriage in Fifteenth-century Italy, Harvard University Press, 2004.

30 Miniaturas de Ovidios moralizados, representaciones en libros dedicados al amor, grandes pinturas muestran para la iconografía renacentista una fuerte presencia de las divinidades relacionadas con el amor (Venus-Afrodita, Eros- Cupido), sus atributos (palomas, rosas, flechas) y los temas más destacados: (la representación de Venus desnuda y fiel al arquetipo de belleza perfecta, la relación entre el amor y el tiempo, la reflexión sobre la doble naturaleza de Venus - celeste y vulgar- o el combate entre amor sacro y amor profano. A ellas se aplican los grandes maestros como Tiziano (Amor sacro amor profano, 1515), Lucas Cranach (Venus y Amor, 1537), Paolo Veronese (Venus, h. 1580), Aníbal Carracci (Venus, h. 1590), Gerardo di Giovanni del Fora (Combate entre Amor y Castidad, entre 1475 y 1500), entre otros. Vid. ELVIRA, M.A.: Arte y mito. Manual de iconografía clásica, Madrid, Sílex, 2008.

31 Lyrico Epitalamio a las Felices Bodas de los Excelentísimos Señores Marqueses de Villena, Condes de Oropesa, etc., mis Señores..., de D. Francisco Manuel Therán, Archivero de la Casa y Estados de los Excelentísimos Señores Duques de Uceda, Condes de Montalbán, mis Señores, Madrid, Por Joaquín Ibarra, 1764. Archivo Histórico Nacional (AHN). Nobleza. FRÍAS, 645/18.

32 La villa de Béjar al matrimonio de los Excelentísimos Señores Marqueses de Peñafiel. AHN. Nobleza. OSUNA, 617/5. 
Amor y de la Casa y la obligación que siente para con sus mecenas. A través de un poema de 10 estrofas de octavas reales, forma habitual en la época tanto en los poemas líricos como en los de estilo más narrativo, el autor se vincula con la tradición de los cantos de bodas (primera estrofa), pide clemencia por el atrevimiento de cantar la de Manuel y Mariana (segunda estrofa) y pasa a advertir que estamos ante un matrimonio decidido no por los intereses materiales sino por la pasión bien dirigida por la virtud que las cualidades personales de cada uno de los amantes han suscitado en el otro (tercera y cuarta estrofa). En esta última el acompañamiento de las imágenes que describen el enamoramiento son las habituales (la flecha del amor, el corazón robado, el cautiverio), pero el mensaje es claro: la primera impresión -el amor a primera vista- se transforma en sentimiento cuando encuentra camino hacia el alma conducido por una "diestra mano" (valoración intelectual de la virtud) ${ }^{33}$. En la quinta y la sexta estrofa, el poeta sigue adentrándose por las características de este amor de la mano de las razones que han encandilado a los esposos entre las que se enumera la inteligencia, la constancia, el talento y la prudencia (sexta estrofa). No se halla la referencia habitual a la belleza de la novia y sí una alusión a la "pasión muda" con la que Mariana idolatraba a Manuel (quinta estrofa). Sabemos que para la novia (Maria Ana López Pacheco y Álvarez de Toledo) era el tercer matrimonio y que pasaba de los 30 años al celebrarse esta boda; en cuanto al novio (Manuel José Pacheco Téllez Girón) tampoco era un cadete sino que había consolidado ya su carrera en las armas con el grado de brigadier. El autor, pasará por alto estas circunstancias y se adentrará, de acuerdo con las imágenes usuales en la preceptiva por el canto a la unión sexual ${ }^{34}$. La séptima estrofa está dedicada a ella, descrita dentro del código de celebración de la sensualidad propio de los epitalamios y que responde a un modelo apuntalado sobre una doble perspectiva. De un lado la "honesta oscuridad" o alusión discreta y poética a los placeres del lecho conyugal y, de otro, la imagen del encuentro sexual como batalla amorosa. Así, "la llama circula por el casto lecho" e "inspira" "lícitas permisiones" en Mariana y el "disfrute del jazmín y de la rosa" en Manuel ${ }^{35}$. El autor termina la estrofa con el deseo que de este "volcán amoroso" salga un óptimo fruto -alusión a la descendencia-. Aunque con la brevedad de los 8 versos que componen la estrofa, el poeta recorre todos los lugares comunes del canto de la unión sexual propia del género. No faltan ni la alusión a Himeneo -el dios del matrimonio-, ni la interpretación el doble papel de los esposos en el lecho nupcial: ella "incauta mariposa", como elemento pasivo, incluso a la defensiva, inmersa en una batalla sensual en la que él toma

33 "Peregrina impresión en dulce calma/ Causó la flecha; pero no fue en vano,/ Pues por la senda, que buscaba el alma,/El camino encontró a la diestra mano:/ Robóla el corazón, y con la palma,/La victoria cantó más soberano,/ Siendo en el robo de tan alto Imperio/ Su mayor libertad su cautiverio." Lyrico Epitalamio a las Felices Bodas de los Excelentísimos Señores Marqueses de Villena, op. cit. (nota 31), fol. 9.

34 "Ya en casto lecho, circulante llama,/ De Hymeneo feliz inspira ansiosa,/ Y al blando alhago rinde soberana/ Su voluntad, incauta Mariposa:/Lícitas permisiones de MARIANA/ Disfruta el Joven de jazmín, y rosa:/ O! quiera el Cielo logren absoluto/ De amoroso volcán óptimo fruto.”, Ibidem, fol. 10.

35 La tradición del canto de bodas reposaba sobre la alocución directa dirigida a los novios apremiándoles a que emprendieran una batalla sensual y gozosa en su lecho. En esta batalla los papeles de género estaban bien fijados: la novia se defendería, casta, y el esposo atacaría. El encuentro sexual, bajo el modelo de militia amoris, encontraba expresión "honesta" en el símil floral presente en la tradición clásica. Vid. PONCE, op. cit. (nota 17), pp. 176-208 y SERRANO, op. cit. (nota 17), pp. 153-170. 
la "rosa". El tema de las flores sobre el tálamo en los epitalamios es objeto de análisis en M. Tanabe ${ }^{36}$ y en Ponce $^{37}$, quienes subrayan la presencia reiterada de la rosa y otras flores, así como imágenes de la abeja y la miel en relación con la descripción del goce del esposo de los atributos femeninos. Concretamente la alusión a la rosa y el jazmín que hace nuestro poeta se halla en el Epitalamio de la primera Soledad de Góngora donde "jazmines llueven, y rosas" 38 . Las consecuencias sociales de esta unión queda reflejada en la estrofa siguiente donde el poeta describe cómo al alba, el palacio brillaba "de encendido de coral y azules flores" en alusión a los colores de los escudos de las respectivas casas: el rojo dominante en el de los Pacheco Téllez-Girón (Manuel) y las flores de lis azules del escudo de los López Pacheco Álvarez de Toledo (Mariana). Las dos últimas estrofas del poema están dedicadas a cantar a los linajes y estados que se unen con el matrimonio y a dar entrada a una segunda parte en la que a través de dos poemas se celebra al linaje de los Pacheco y el de los Toledo-Pacheco.

Este es, pues, un canto nupcial ajustado a la preceptiva del epitalamio cortesano, donde el autor, obligado por la consideración que debe a sus mecenas, vierte sus conocimientos sobre los requisitos de un buen matrimonio del siglo XVIII ajustándolos más o menos a la boda que le sirve de pretexto. De naturaleza diferente es el epitalamio que la ciudad de Béjar encarga con motivo del casamiento de los marqueses de Peñafiel, futuros duques de Osuna ${ }^{39}$. En este caso conocemos el nombre del autor, Manuel Miranda, por las cartas que se cruzan entre el Ayuntamiento de Béjar y el duque de Osuna en mayo de 1803; en una de ellas la corporación informa al mismo de la alegría de la ciudad por un acontecimiento tan próspero como es el referido enlace y remite el epitalamio y, en respuesta el duque agradece al Corregidor y al Ayuntamiento de Béjar sus felicitaciones y manifestaciones de alegría, así como el epitalamio ${ }^{40}$. Tampoco ofrece el autor en la canción nupcial el nombre de los contrayentes, aunque podemos deducirlo por la fecha y una alusión a la "graciosa Beaufort", que nos indica que se trata de la boda de Francisco de Borja Téllez Girón y Alonso Pimentel con $\mathrm{M}^{\mathrm{a}}$ Francisca de Beaufort y Toledo ${ }^{41}$, celebrada en Madrid, en marzo de 1803. En este caso, aunque el poeta es fiel a los temas que recoge la tradición clásica de los epitalamios, no elude ni la realidad de las personas a las que celebra ni tampoco la de la ciudad que le encarga el canto de bodas. Mucho más extenso que el anterior -es un canto nupcial bien fijado a la realidad que rodea a la boda-, se inicia con un sencillo saludo al duque con motivo del "venturoso enlace". Ya desde el

36 TANABE, op. cit. (nota 18), pp. 65-68.

37 PONCE, op. cit. (nota 17), pp. 176-208.

38 TANABE, op. cit. (nota 18), p. 66.

39 La villa de Béjar al matrimonio de los Excmos. Señores Marqueses de Peñafiel (1803), AHN. Nobleza. OSUNA, C. 617 , D.5. s.f -28 folios-

40 En la carta de 1 de mayo de 1803, el Ayuntamiento escribe al duque y en respuesta a la carta, el 31 de mayo de 1803, el duque de Osuna agradece en su nombre y en el de la duquesa las demostraciones de afecto por la boda y el epitalamio "trabajado por don Manuel Miranda" y afirma que se lo ha enseñado a los marqueses de Peñafiel que lo "han apreciado todo mucho y quedan mui agradecidos a la buena lei de ese Ayuntamiento y vecindario", AHN. OSUNA, 617/5.

41 Los contrayentes eran los hijos de de Pedro Alcántara Téllez Girón (fallecido en 1785) y M ${ }^{\mathrm{a}}$ Josefa Alonso Pimentel, duques de Osuna -padres del novio- y Fréderic-Auguste Alexandre de Beaufort-Spontin, conde duque de Beaufort y $\mathrm{M}^{\mathrm{a}}$ de los Dolores Leopoldo de Toledo y Salm Salm, padres de la novia. 
comienzo, el autor deja ver donde podrá el acento, aludiendo a la condición tanto del duque actual como del futuro, el marqués de Peñafiel, de señor de vasallos a los que les ha de preocupar, sobre todo, la salud y el bienestar de los pueblos que forman sus estados. Se imagina al duque tranquilo al comprobar que su hijo está capacitado para sucederle cuando sea preciso. Toca a continuación describir como se ha forjado este "nudo de amor" y, tras la alusión a Himeneo, el autor acude a las figuras habituales que cantan la victoria del amor como una "sacra tea" que infunde en las almas de los jóvenes ternura, sensibilidad y constancia. Una vez encendida la llama "del deseo voraz", la religión autoriza con el rito el "misterio profano" del amor y permite la consumación del mismo ${ }^{42}$. Referido el amor como misterio, como amor profano y no como amor divino, lo que es un matiz muy interesante en el sentido de modernización del concepto del amor, y significado como deseo, en este caso "voraz", el autor dedicará un buen número de versos a las prendas concretas que reúnen los cónyuges, especialmente el novio. Respecto a él no sólo invocará la tradicional excelencia del linaje, que lo era, y su estirpe de espadas nobles destacados en la lucha contra los enemigos de la patria, sino muy especialmente la educación recibida. Se subraya la utilidad de la formación del marques de Peñafiel: el estudio de las Leyes, la Moral, la Religión y la Historia, como corresponde a alguien destinado a gobernar tierras y vasallos, sin despreciar el aprendizaje de la civilidad, la literatura, la educación física y la industria. En este sentido sabemos que las alusiones no eran un mero recurso retórico, sino que el futuro duque y su hermano habían recibido una cuidada educación y no sólo en aquellas materias a que obligaba la posición social de un buen cortesano -baile, dibujo, poesía, lenguas extranjeras y clásicas, bellas artes - sino también en Gramática, Lógica, Metafísica, Matemáticas, Física, Política, Economía, disciplinas en alza entre los valores del Setecientos. Todo ello lo había alcanzado el novio con el asesoramiento de su preceptor Diego Clemencín y Viñas, un erudito y humanista, interesado por la pedagogía. Respecto a la novia, "la graciosa Beaufort, dulce pimpollo", las referencias serán las habituales. Frente al arte, la ciencia y el estudio que son las cualidades del novio y aparte del linaje que poseen los dos, el milagro aparece como prenda femenina por excelencia. El milagro de su seducción, su belleza, su rubor, su ternura y su fidelidad ${ }^{43}$. La descripción recurre a los tópica con los que se interpreta la belleza femenina, sintetizados en la visión de la cara como espejo del alma y elevando el rubor a virtud como indicio de castidad, sensibilidad y fidelidad.

42 "La tierna conmoción, la risa, el juego/Presagian la fortuna e Hymeneo/ en pos sigue de Amor y de las Gracias. /El mysterioso Amor envanecido/ celebra su victoria, y por la mano/ A los amantes cónyuges conduce,/ soplando en las dos almas la ternura,/ La sensibilidad y la constancia./ El Dios descubridor la sacra tea/ Presenta al corazón, y malicioso/ Con encendido escrúpulo les muestra/ El deseo voraz, trémulamente/ Confundiendo el cariño y la existencia./ La augusta religión, autorizando/ El misterio profano, consagrolo/ Con respetable rito, y consumose/ El fortunado enlace." , La villa de Béjar...op. cit. (nota 32)

43 "La graciosa Beaufort, dulce pimpollo/ De constancia y cariño, por la mano/ De la cuidosa Venus adornada,/ Te ofrece sus milagros, que tu mente/ con inquietud absorta escrupuliza./ Modelo de unas gracias seductoras,/ En el semblante la ternura rie,/ Intérprete del alma, que se dobla/ Al fiero arranque del amor terrible./Beldad sensible, en quien asoma diestro/ el rubor persuasivo dulce indicio/ De la justa pasión, que le colora/Allí está el corazón, el generoso/origen de tu dicha, que te jura/Fidelidad eterna. Allí el carácter,/Que ordenando pasiones encontradas,/sagaz las une en plácida armonía.", Ibidem. 
La incitación a la unión sexual también se contiene aunque apenas esbozada en la presente canción nupcial con las alusiones a Himeneo y al amor ardiente que fecundiza ${ }^{44}$. Los cónyuges tenían ambos 18 años en el momento de la boda, celebrada en Madrid y cuyos ecos llegan a Béjar que también, según nos cuenta el autor con detalle, la celebra. El contento del pueblo se expresa en el "gozoso desorden" con el que deja el trabajo y acude a la plaza a aplaudir y a festejar, en las risas y aplausos con que son acogidos los fuegos artificiales, los cohetes, la novillada que tiene lugar después de la misa y el resto de las celebraciones que siguen hasta la noche. Entonces acuden a la plaza, junto a un palacio ducal con torreón decorado para la ocasión con farolas dispuestas en círculos y arcadas, ramos de boj y otros adornos, los labradores con sus hijos. También acuden las mozas, arregladas con sus mejores atavíos, y los mozos con ramas de laurel y hachas encendidas, -atributo con el que se suponía que Himeneo se presentaba en las bodas-, entregándose a una fiesta de la que saldrán nuevos amores $^{45}$. Como la novia ofrece los milagros de su atractivo a un joven circunspecto y reflexivo, en la descripción de estos bailes el autor insiste en el protagonismo de las mozas y sus atributos físicos activando la hoguera del amor. Pero antes de adentrarnos en la cuestión de la guerra de sexos que la cultura del amor de estos siglos revela, es preciso referir que el autor no termina su canción de boda aquí, sino que a lo largo de cinco folios más se adentra en lo que para la ciudad de Béjar es algo fundamental tras la celebración de los fastos. Cesan los festejos, se vuelve al trabajo, y el vasallo ve su esperanza y su paz amenazada por la situación de una industria clave para la ciudad: la pañería, en crisis por la competencia de los paños ingleses. Si en el epitalamio barroco las circunstancias reales parecían estar ahí sólo como pretexto para la celebración de una boda, en este, en el ocaso del género, la boda parece el pretexto para insuflar a los gobernantes el ánimo suficiente para practicar una política real. Una política que tenga en cuenta que las artes, las ciencias, la industria y el comercio son los que transforman el "bárbaro desorden" de los pueblos en una sociedad civilizada e ilustrada y una política que fiel a su empeño de sabio equilibrio, y no obstante el respeto por los pactos y el derecho, sepa hacer frente a la competencia desleal de los paños ingleses que inundan los mercados por mar y tierra. No tiene alternativa el bejarano, dice el poeta, en una tierra poco apta para la agricultura, así que espera de los señores, del actual y del futuro, cuando se ponga al frente del "escuadrón", que dicten leyes y hagan feliz al pueblo ${ }^{46}$.

Si la existencia de una relación directa entre amor y deseo se halla en la cultura amorosa de la edad moderna y se incorpora como algo necesario en las reflexiones,

44 "Entre la multitud, que al instruento/Harmónico se agita. La alma Venus/ Conducida en el carro, a la alegría/ manda imperiosa, señalando al brazo/ Do el victor fixa de la voda fausta./ Sus orgullosos hijos, las dos almas/ Del placer y la dicha, el Hymeneo,/El Dios de libertad, y el purpurino/ Amor en pos la siguen; presagiando/ Fidelidad y ardor que fecundicen./, Ibidem.

45 "La feliz ocasión despierta al joven/Dulcísimas pasiones. Las explica/con airosa aptitud en la ligera/ Danza enrredosa. ¡Qual la Bejarana/Beldad se ruboriza! Sus encantos/ Anima el movimiento persuasivo./Las Gracias prepararon los adornos/De los senos que irritan, y ellas saben/Manejar el airoso continente./Ora la risa del rosado labio/se desprende traviesa, y en la buelta/Fugaz la joven del peligro escapa./Ora se eleva el torneado seno,/Y rendido al cansancio no palpito/ con la justa igualdad... ay ; fugitivo/ El corazón se vence... que el terrible/Amor le cerca en derredor!, Ibidem.

46 Ibidem. 
argumentaciones y celebraciones sobre el amor matrimonial, hay otro lugar común cuya presencia no le va a la zaga. En los epitalamios se describe una vivencia del amor atravesada por roles de género y las novelas cortesanas y sentimentales darán un paso más al plantear no ya una vivencia diferenciada del amor por parte de hombres y mujeres, sino también los conflictos que esta diferenciación plantea. Es el caso de una de las novelas más famosas del XVI español, la Cárcel de amor (1492), de Diego de San Pedro, traducida a varias lenguas y que pasará al acervo de la cultura amorosa de los siglos XVI y XVII, mediante la conversión de algunas de sus expresiones, en lugar común en la argumentación de tratadistas del amor como Cristóbal de Fonseca ${ }^{47}$. La protagonista de Cárcel de amor, la princesa Laureola, no tiene nada que ver con la inteligente Sofía que ponía en un continuo brete a Filón en el Diálogo de León Hebreo. Laureola casi no existe más que como referencia, como objeto de adoración; el único que ama, el que expresa sus sentimientos, el que lucha por convertir en realidad su deseo es el protagonista masculino -Leriano- que se deja morir de amor no sin antes defender por última vez a su esquiva dama a la que no culpa de sus desplantes porque, para él, ella no hace más que cumplir su papel: guardar la honra como una perfecta dama. Pero lo que nos interesa de esta novela, best-seller en la España de los siglos XVI y XVII, es la relación casi indisociable que plantea entre amor y guerra de sexos, o por mejor decir, del amor entre dos sexos que ocupan posiciones diferentes en la sociedad ${ }^{48}$.

De ambas problemáticas (Amor/Razón; Amor/Guerra de sexos) se hallan referencias en el pensamiento de Teresa de Jesús, una de las grandes amadoras del XVI español, una loca de amor como ella misma se define en muchas de sus páginas escritas siempre autobiográficamente. Páginas en las que investiga sobre la naturaleza y el lenguaje del amor místico (Conceptos del amor de Dios, 1575) ${ }^{49}$, describe el largo camino que le conduce al encuentro místico con Dios (Libro de la Vida, 1562) o la naturaleza y las consecuencias de esos encuentros amorosos (Castillo interior, $1577)^{50}$, donde utilizará el símil de la cárcel de amor tan en boga en el XVI. Son muchas las páginas en las que desglosa cómo se llega a ese amor, pero sólo quiero traer a colación dos comentarios que tienen la virtud de apostillar la doble perspectiva que he sugerido. Respecto a los términos excluyentes con los que se plantea el tema del matrimonio (amor o interés), Teresa, que suele comparar el matrimonio con Dios con el matrimonio en el siglo, explicando una fase del viaje místico que todavía no es la de la boda espiritual, escribe: "Paréceme a mi que la unión aún no llega a desposorio espiritual, sino como por acá cuando se han de desposar dos, se trata si son confor-

\footnotetext{
47 DE FONSECA, C.: Tratado del Amor de Dios. Segunda parte, Madrid, Luís Sánchez, 1620, p. 681.

48 DE LA PASCUA, Ma . J.: "Entre la civilidad y la guerra de sexos: el poder del amor en el mundo moderno", en CANDAU, Mª L. (ed.): Las mujeres y las emociones en Europa y América (2014), en prensa.

49 DE LA PASCUA, Ma . J.: "Amor místico, amor sensual: sexo, amor e identidades femeninas (siglos XVI-XVII)", en DEL VAL, Ma. I., GALLEGO, H. (eds.): Las huellas de Foucault en la Historiografia: Poderes, Cuerpos y Deseos, Barcelona, Icaria, 2013, pp. 163-198.

50 DE LA PASCUA, M ${ }^{\text {a }}$ J.: "El jo en l'escriptura religiosa femenina.", Afers. Full de recerca i pensament, nº 77 (2014), pp. 23-51.
} 
mes, y que el uno y el otro se quieran y aún que se vean, para que más se satisfaga el uno del otro" $"$.

El otro comentario se articula en torno a la guerra de sexos. Ella que no quiso casarse, que tampoco quiso ser monja, describe la naturaleza de su unión amorosa con Dios, proponiendo una imagen muy cotidiana. Según Teresa, la naturaleza del desposorio con Cristo difiere del de los esposos terrenales porque en el matrimonio terrenal, la esposa debe adaptarse a estar como está su marido -"si él triste, triste, si alegre, alegre"-; sin embargo, "en el matrimonio espiritual, es Cristo el que se hace sujeto - esclavo o siervo- y quiere seamos señoras y mandar en él según voluntad. Si una está triste, le mira en la pasión; si alegre, en la resurrección..."52. Concluyendo, en el matrimonio el cóctel tiene como ingredientes amor, entendimiento y posiciones diferentes para los esposos, siendo la de la esposa de subordinación claramente.

En el siglo XVII, los términos del debate se mantienen. Este es el sentido expreso de uno de los tratados sobre el amor más famosos en la España moderna, el Tratado del amor de Dios de Cristóbal de Fonseca, cuyo primer tomo apareció en las últimas décadas del XVI y constituye el leitmotiv de la novela cortesana donde el debate entre buen amor y mal amor es el soporte más frecuente de su estructura y también el motivo dominante de la trama y del desenlace. La especificidad de éste -fatal si se trata de un amor malo/feliz, generalmente, si es un amor honesto- redunda en la dicotomía amor malo-amor bueno y contiene muy bien guardado, como el fruto dentro de una concha, la guerra de sexos porque, en última instancia, la responsabilidad del mal amor es siempre de las mujeres; no de todas, pero sí de aquellas que no responden al ideal de una mujer cuidadosa con su honra y sometida a la autoridad de maridos y padres.

No difiere mucho la temática cuando se utiliza para el análisis una literatura "menor", literatura efímera, de fácil difusión; los llamados "papeles ligeros" que gustaban al vulgo y que en sus composiciones poéticas, desde el XVII en romance, narraban aventuras amorosas. Aventuras que en su voluntad moralizadora, recreaban la excelencia femenina a partir de la castidad, la resignación la obediencia al esposo y la defensa numantina de la virtud y la honra. La exhortación al mantenimiento de la armonía en el matrimonio recaía siempre en las mujeres, destinadas a convertirse en "monstruos de virtud" y de paciencia, consejo reiterado también en Recetas e Instrucciones para el matrimonio abundantes, asimismo, entre los pliegos de cordel de los siglos XVII y XVIII ${ }^{53}$, así como en los llamados libros de estados ${ }^{54}$.

51 DE JESÚS, T.: Castillo interior o Las Moradas (1577), en Obras Completas de Teresa de Jesús (ed. de Luis Santullano), Madrid, Aguilar, 1988, Moradas V, cap. IV, p. 427.

52 DE JESÚS, T.: Libro de la vida en Obras de Teresa de Jesús, op. cit. (nota 51), p. 344, vid. DE LA PASCUA, $M^{\mathrm{a}}$. J.: "Corps humillé, corps glorieux. Paradoxe $\mathrm{d}^{\prime}$ un langage d'auto-affirmation dans la mystique féminine (XVIème et XVIIème siècles)", en Colloque Rapports hommes/femmes dans l'Europe moderne: Figures et paradoxes de l'enfermement, Colloque LLACS-IRCL, Université Paul Valéry, Montpellier III (Montpellier, nov. 2012), http://halshs.archives-ouvertes.fr/halshs-00841145, (en prensa).

53 GOMIS, J.: "Romances conyugales. Buenas y malas esposas en la literatura popular del siglo XVIII", Tiempos Modernos 18 (2009/1).

54 BRANDERBERGER, T.: Literatura de matrimonio (Península Ibérica, siglos XIV-XVI), Zaragoza, Pórtico, 1997 y MORANT, I.: Discursos de la vida buena. Matrimonio, mujer y sexualidad en la literatura humanista, Madrid, Cátedra, 2002. 
En el XVIII se van a mantener estos dos temas proporcionando esqueleto a las representaciones del amor. No obstante, la tensión entre tradición y modernidad se manifiesta también en el mundo afectivo donde las mujeres van abriendo un espacio reivindicativo en el que se hace oír la necesidad de una redefinición de las relaciones afectivas entre los sexos, algo así como una nueva política sobre lo privado ${ }^{55}$. En el marco del nuevo sentimentalismo en boga que descansa sobre la idea de los buenos sentimientos como un fruto, natural y a la vez cultivado, llamado a convertirse en el nuevo referente social de civilización, la demanda de amores virtuosos y llenos de buen juicio, permitirá el cuestionamiento de algunos lugares comunes tradicionales. De paso, también, cobrarán presencia la valoración de la dimensión personal del amor, la defensa del mérito frente al linaje o el papel de la libertad y la decisión personal frente a la autoridad paterna. En este contexto, el desacuerdo de las mujeres con un imaginario amoroso plagado de funciones sociales y estatus discriminatorios respecto a su sexo, se empieza a percibir con fuerza en algunas de las protagonistas de las novelas sentimentales. Una esposa abandonada que toma la iniciativa en la búsqueda de su amor (Eumenia, 1805), una amante sincera y decidida como La filósofa por amor (1799), la apasionada y casi romántica joven india que no duda en poner fin a su vida ante el desengaño (Oderay,1804) o una nueva relación amorosa dibujada, bien que a través del protagonista masculino, como una relación entre iguales (La Serafina, 1798), constituyen nuevos modelos para la vivencia del amor, en línea con las protagonistas de las dos grandes novelas de referencia (Pamela, 1740 de Richardson o la Nueva Eloísa, 1761, de Rousseau), y cuyas tramas y desenlaces empiezan a cuestionar el papel pasivo de las mujeres en las relaciones amorosas. Aunque estas demandas no tienen la virtud de cobrar realidad sólo por ser enunciadas, constituirán nuevos referentes, abriendo paso a una relectura del código tradicional de la "enfermedad del amor" que, cuando menos, enfatiza la sospecha sobre el mismo ${ }^{56}$. Esta había sido el argumento reiterado de una mujer escritora, novelista del amor y del desengaño en el XVII: María de Zayas; pero la sospecha no se queda sólo en el ámbito literario o ensayístico: los expedientes judiciales que como demanda por incumplimientos de esponsales, raptos o abandonos se conservan en archivos españoles procedentes de estos siglos son un buen testimonio de ello ${ }^{57}$.

55 DE LA PASCUA, M ${ }^{\mathrm{a}}$. J.: "Tradición y cambio en el lenguaje de los afectos: el discurso literario", Ayer. Revista de Historia Contemporánea 78 (2010) 2, pp. 47-68.

56 Ibidem, pp. 66-68.

57 El número de trabajos realizado a partir de ellos para el siglo XVIII es ya notable por lo que sólo citaré algunos: GIL, A.: Historia de la violencia contra las mujeres. Misoginia y conflicto matrimonial en España, Madrid, Cátedra, 2008; MORGADO, A,: "El divorcio en el Cádiz del siglo XVIII", Trocadero. Revista de Historia Moderna y Contemporánea, 6-7 (1994-95), pp. 125-135; RUIZ, M.: Matrimonio, moral sexual y justicia eclesiástica en Andalucía Occidental: la tierra llana de Huelva, 1700-1750, Sevilla, Universidad de Sevilla, 2011; GAMBOA, Á.: "Los procesos criminales sobre causa de estupro ante la Corte y Consejo Real de Navarra (1750-1799): Aproximación a la sociedad Navarra de la segunda mitad del siglo XVIII", Príncipe de Viana, 4 (1988), pp. 111-119, DUBERT, I.: "Los comportamientos sexuales premaritales en la sociedad gallega del Antiguo Régimen”, Studia Histórica. Historia Moderna, IX, (1991), pp. 117-142, DEMERSON, J. y P.: Sexo, amor y matrimonio en Ibiza durante el reinado de Carlos III, Mallorca, El Tall, 1993; DE LA PASCUA, Ma . J.: Mujeres solas. Historias de amor y de abandono en el mundo hispánico, Málaga, CEDMA, 1998, o ÁLVAREZ, Á.: Transgresiones a la moral sexual y su castigo en Gipuzkoa durante los siglos XVI, XVII y XVIII. Tesis Doctoral, Universidad del País Vasco, 2010. 
Más allá de estos discursos sobre el amor, el historiador de los afectos se empeña en la localización de un material que supuestamente hable de forma más personal de los "grandes" temas relacionados con él. Al hacerlo, busca bellas y conmovedoras palabras insertas en relatos individuales íntimos, profundos, presididos por una lógica llamémosle "totalitariamente amorosa". Y se muestra decepcionado cuando en la documentación privada no halla esas grandes palabras o no las halla en relatos presididos por una única lógica, la amorosa. Cuando se localizan algunas de estas fuentes, la posición resultante oscila entre una cierta estupefacción porque las palabras suenan vacías, extremadamente literarias, o bien no se sabe qué hacer con ellas. Después de comentar que un amante dirige a otro la expresión corazón mío, ¿qué más decir? La afirmación de que estamos ante la muestra de un amor apasionado es obvio que no procede; sabemos que eso no es exacto o que, al menos no puede saberse si lo es. El problema es agudo porque el historiador al constatar esta declaración no puede afirmar que está constatando una experiencia amorosa, no al menos por la sola presencia de esas palabras. A mi modo de ver, en esta tarea se inserta una doble problemática. Por un lado, la que atiende al lenguaje que utilizamos para expresar el amor o, más propiamente, la relación de éste con la emoción sentida. Por otro lado está la problemática que tiene que ver con el tiempo. Aspecto este que, como historiadores, no puede menos de preocuparnos y fascinarnos, pero que a veces, pasamos por alto. El tiempo en una doble perspectiva, en lo que afecta al discurso o al lenguaje del amor, que sabemos no sigue el ritmo temporal de otros aspectos culturales, no al menos en todo su amplio espectro. A ello nos referiremos con algún ejemplo más adelante. Y el tiempo, y esto es muy importante también, en una variable más individual en el sentido del ritmo del tiempo de la vivencia del amor. En este último sentido el historiador tiene que vencer una ilusión óptica que le lleva, como a todos los individuos en sus propias vivencias, a imaginar la pasión amorosa como indivisible y continúa; un estar-en-sí-permanentemente-amando, cuando es más bien a ratos. El amor como emoción sentida se descompone en amores sucesivos o en momentos diferentes aunque el objeto sea el mismo- con distinta intensidad de percepción para el sujeto que lo vive y, desde luego, contextualizada en su vida.

Respecto a la problemática enunciada en primer lugar, la del lenguaje, es preciso plantearse si constatar la presencia de una figura de amor es decir algo más que eso. De la constatación de una expresión como "corazón oprimido", en sus distintas versiones de corazón tiranizado o herido, es obvio que no hacemos historia. El gran experto en el arte de la práctica del amor, Ovidio (Siglo I a.C) se lamenta de las saetas que Cupido lanzaba a su corazón, tiranizándolo y oprimiéndolo ${ }^{58}$; la monja portuguesa Mariana Alcoforado, se dolía en su cuarta carta de la tiranía de un corazón que oprimía su pecho ${ }^{59}$, con imágenes similares a las que Cadalso, un siglo después, utilizará para llorar la muerte de Filis ${ }^{60}$. También García Lorca, en la poesía Alba (1927) alude a su "corazón oprimido siente junto a la alborada el dolor de sus amores

58 OVIDIO, P.: Los amores, Santa Fe, El Cid editor, 2004, Elegías I y II.

59 Cartas de amor de la monja portuguesa Mariana Alcoforado (1669). (Trad. de Carmen Martín Gaite), Barcelona, Círculo de Lectores, 2000, p. 69.

60 "Niño temido por los dioses y hombres,/ hijo de Venus, ciego amor tirano,/ con débil mano vencedor del mundo, /dulce Cupido./ Quita del arco la fatal saeta,/deja mi pecho que con fuerza heriste/ cuando la triste, la 
y el sueño de las distancias" ${ }^{61}$ y de forma más elaborada y particularmente hermosa en Donde habite el olvido, (1932-33), Luis Cernuda, refiere un amor que se esconde, como acero, en el pecho ${ }^{62}$. Siglos I a.C, XVII, XVIII y XX, seguro que podríamos encontrar muchísimas más alusiones en poesías, canciones, y en la correspondencia personal. Lo mismo podríamos decir de muchas otras figuras que constituyen la parte nombrada más visible de ese imaginario amoroso propio de una cultura. He analizado algunas de las que aparecen en las cartas publicadas en repertorios conocidos (Otte ${ }^{63}$, Sánchez-Testón ${ }^{64}$ ) o en las recogidas por mí de expedientes judiciales y requisitorias, en un trabajo que se publicará próximamente ${ }^{65}$. ¿Como historiarlo pues? Palabras grandes o pequeñas, a veces mejor pequeñas, sólo son valorables a partir de los contextos en los que se producen y son estos contextos los que pueden guiarnos por una historia del amor. Contextos discursivos que nos ayudan a adentrarnos por la funcionalidad de las palabras ofreciendo la perspectiva global de algo de naturaleza fragmentaria. Aquí, obviamente la metodología de la semiótica requiere el análisis de cada figura en el contexto del discurso a fin de reconocer los ideologemas y captar cómo se articulan lo social y lo textual. Pero también es necesario el recurso a contextos sociohistóricos y circunstanciales a fin de seguir en esa comprensión de la articulación entre la experiencia individual y el imaginario común que carga aquella de sentido. Y aquí es donde la problemática, lenguaje-tiempos del amor, encuentra la clave: en los contextos. Aún más. En los contextos de cotidianeidad relacionados con las vivencias de los individuos, mujeres u hombres.

Es cierto que la replica a esos discursos a los que antes me refería se encuentra en esas expresiones, -figuras del amor según Roland Barthes- ${ }^{66}$ con las que se representa e identifica lo que se siente, en un proceso que tiene tanto de esfuerzo reflexivo como de "atrapar al vuelo". Figuras como ese "corazón oprimido", partido o asaeteado, que poseen su propio ritmo temporal, pero cuya secuencia liberadora de emociones se hace presente en cada individuo asociada a una vivencia, a una creencia, estas sí, temporal e históricas, en un proceso, como apuntábamos más arriba discontinuo, al que sólo la ilusión de la unidad de una vida, presta esa ilusión de continuidad. Es ahí donde el contexto ayuda al historiador a dar sentido a la proyección que sobre el discurso amoroso, a partir de sus figuras construyen los individuos de una determinada época. No interesan tanto las figuras repetidas en tantos y tantos textos, cuanto la funcionalidad de estas y su destino en una relación concreta, relación social y cultural, con el otro. Para explicarla

divina Filis/me dominaba./ en Poetas líricos del siglo XVIII. Antología. (Selección, estudio y notas de Higinio Capote), Zaragoza, editorial Ebro, 1980, p. 103.

61 GARCİA LORCA, F.: “Alba”, (1927), en Antología poética, Barcelona, Orbis, 1982, p. 67.

62 "En esa gran región donde el amor, ángel terrible,/ no esconda como acero/ en mi pecho su ala/, sonriendo lleno de gracia aérea mientras crece el tormento", en CERNUDA, L.: Antología poética, Madrid, Alianza editorial, 1978 , p. 50.

63 OTTE, E.: Cartas privadas de emigrantes a Indias, 1540-1616, México, F.C.E., 1996.

64 SÁNCHEZ, R., TESTÓN, I.: El hilo que une. Las relaciones epistolares en el Viejo y el Nuevo Mundo, siglos XVI al XVIII, Mérida, Universidad de Extremadura, 1999.

65 DE LA PASCUA, Ma. J.: "Regulación de los afectos y cultura del amor en la sociedad hispana de la época moderna" XII Reunión Científica de la Fundación Española de Historia Moderna (Sevilla, 2014), en prensa.

66 BARTHES, R.: Fragmentos de un discurso amoroso (1977), Madrid, Siglo XXI, 1982. 
las otras palabras, tal vez más pequeñas, los gestos que también las acompañan, los soportes en los que se hallan y se dirigen, son útiles. Las precauciones, sin embargo, son obligadas. Las palabras, a veces, es como si estuvieran mal colocadas, sus significados más aparentes no funcionan y los gestos nos devuelven una casuística más eficaz que la sola retórica para llegar a esos territorios singulares donde las prácticas emergen adosadas a funcionalidades concretas. Porque ¿qué significan esas figuras del imaginario del amor? Más allá de las afirmaciones y representaciones que suelen hacerse ante la persona amada, ¿cómo se materializa, en el día a día, el sentimiento-vivencia encriptado en ellas? Proverbios y refranes acompañan una sospecha generalizada sobre las palabras -“Obras son amores y no buenas razones"-, y más allá de constatar la existencia de un lenguaje amoroso y su identificación con tal modelo de amor, el historiador debe descender a lo concreto sin olvidar su inmersión en un proceso relacional. Situarse en el paradigma benjaminiano ${ }^{67}$ para dar valor a las grandes palabras y atreverse a romper su cáscara sin temor a encontrar un hueco -porque muchas veces podemos efectivamente encontrar sólo un hueco-. Las palabras pequeñas, insertas en el contexto de la cotidianeidad, nos abren los dominios de la práctica amorosa y de las pequeñas, siempre pequeñas, libertades con las que ejecutamos, danzamos, al son del modelo amoroso. Buscar en la correspondencia personal, en los testamentos, en los desistimientos de promesa de matrimonio, en los legados, en las demandas de divorcio o nulidad, en los expedientes por causa de bigamia o de estupro, en fin en todos aquellos documentos donde quedan indicios de la práctica del amor, el sentido práctico de las figuras amorosas y del imaginario del amor con el que se construyen históricamente los sentimientos. Un sentido práctico que obedece a intereses de diverso tipo. Si buscamos, hallaremos que no todo se reduce a unas cuantas palabras hermosas, fieles reflejos de buenos sentimientos y que la mentira, el engaño, el abandono, la ausencia, los celos, incluso la desesperación y la violencia acompañan la vivencia del amor con tanta frecuencia, al menos, como las mieles que sugieren los bellos mensajes.

\section{Omnia Vincit Amor (Virgilio, Egloga X.69)}

Detrás de las contradicciones que acompañan los testimonios de un hombre y una mujer acusados ante la Inquisición de bigamia, y aunque en todo el expediente no encontremos ninguna alusión al amor a través de bellas figuras, se hallan indicios suficientes para comprender una relación amorosa. Nos situamos en Cádiz, en 1763, donde un hombre de 44 años y una mujer, son acusados de bigamia. Ella, guipuzcoana, de Fuenterrabía; se había casado por poderes, trece años atrás, embarazada de un novio por entonces ausente en Indias. A pesar de las promesas, este no había regresado y ella había empezado una nueva relación con un pamplonés, a la sazón, sargento. Tras la denuncia por bigamia, los amantes declararon que su voluntad había sido la de contraer matrimonio y para ello habían preguntado a confesores y conocidos cómo podían hacerlo. Aquí sus versiones y las que aportan luego como testigos los susodichos "expertos" difieren. Los bígamos afirman que un fraile capuchino les había advertido de la necesidad de

\footnotetext{
67 Para Benjamin no supondría quedarse en lo concreto sino deambular por ello en la búsqueda de lo más cercano a su vivencia-significado, BENJAMIN, W.: Libro de los Pasajes, Madrid, Akal, 2009.
} 
obtener una licencia del marido de ella para luego ir a Roma a obtener el permiso del Papa, y que un miembro de la Inquisición se lo había confirmado. Ella, por su parte, aseguraba que había aprovechado el viaje a La Habana de un conocido para pedir a su marido la licencia y que, aunque no obtuvo el papel, si había conseguido una autorización verbal. En estas consideraciones, se habían ido a Roma. Un cura que confesaba en español en la iglesia de San Pedro, había advertido a la novia que sin dispensa de $\mathrm{Su}$ Santidad no podía casarse. El novio, por su parte, había consultado con otros que, según él, le dijeron que si declaraba bajo juramento que ella había obtenido verbalmente una licencia de su marido podían casarse sin temor. Finalmente habían contraído matrimonio en la Iglesia de San Pedro y, tras 20 días, volvieron a España y se instalaron en Cádiz. Más allá de los hechos, que de por sí constituyen indicios sólidos de la voluntad de esta pareja por estar juntos, algunos comentarios confirman su determinación en este proyecto. Ellos sabían que necesitaban la licencia por escrito para iniciar los trámites de nulidad y aseguran que estuvieron esperándola, pero "como pasaba mucho tiempo y no venía ninguna embarcación", su novio le propuso el viaje a Roma advirtiéndole que sería empresa dificultosa y ella aceptó porque estaba determinada a casarse. Una vez en Roma, su novio sorteó las dificultades, argumentándole que, como tras el matrimonio anterior no había habido velaciones ni las bendiciones al uso se podían casar y, según ella, obró de buena fe. Los testimonios del resto de los testigos, sin embargo, coinciden en desmentir la versión de la pareja: fueron advertidos que su marido no daba la licencia sin recibir previamente una de su parte y también de la imposibilidad de casarse estando unida como estaba la novia a otro por legítimo matrimonio ${ }^{68}$. En el expediente en cuestión no hay una ni una sola palabra de amor, sí expresiones familiares en la normativa que regulan las relaciones entre hombre-mujer ("trato ilícito" "escrúpulos", "evitar grandes daños y discordias", etc.), pero es obvio que esta relación, que duraba ya más de cuatro años, era una relación iniciada por voluntad de los dos amantes, determinados, contra viento y marea y conscientes que transgredían la ley, a luchar por su amor. Ejemplos como éste, de cómo los jóvenes sortean las dificultades para vivir su amor, pueblan los expedientes judiciales de historias de afectos vividos entre transgresiones y dificultades por acomodarse a las normas. Aunque en ellos los testimonios remitan a una casuística legal en torno a la regulación de los matrimonios, en el envés de estas prácticas es posible encontrar, en íntima trabazón, afectos e intereses.

Algunos años antes, en 1745, en el tribunal inquisitorial de Sevilla, se sigue causa contra Miguel Connabet, calvinista, "hereje protestante" y Catalina Couto, católica; ambos vecinos de Cádiz, donde él se había establecido con 23 años -en el momento de la denuncia tenía 40- con Casa de Comercio. La esposa, Catalina, de 36 años, natural de Madrid, había vivido en París entre los seis y los doce años, instalándose con sus padres en Cádiz donde había conocido a su futuro marido. La causa comienza por la denuncia del canónigo y comisario del Sto. Oficio en Cádiz, que había tenido noticia de la celebración de un matrimonio entre un hereje y una católica. Este matrimonio mixto, "secreto y con dispensa de ordinario", según el parecer de este comisario, contravenía el sentir de canonistas y moralistas y era sumamente peligroso en Cádiz, donde por razón de su comercio había establecidos "varios heresiarcas". La indagación en la que

68 AHN. Inquisición, L. 3721. Exp. 49 
no voy a entrar en este momento, concluye con la constatación de que el matrimonio se ha celebrado con la dispensa del obispo, quien al parecer ha actuado "un tanto ligeramente" pero también engañado por los contrayentes. Estos han argumentado que habían solicitado dispensa al Papa y "dejado caer" que éste la había otorgado, que la contrayente estaba embarazada y enferma, con riesgo de la honra, y aún más de sufrir la reconvención de su padre y con riesgo de su vida por todos estos avatares. Ninguno de estos extremos se confirmaron -ni había licencia papal, ni ella estaba embarazada, ni corría riesgo su vida por la reacción que pudiera esperarse de su padre pues este había fallecido- y la declaración jurada del novio, compromiso que este había adquirido prometiendo adoptar la fe católica una vez tuviese conocimiento de la doctrina, tampoco se había realizado ${ }^{69}$.

A comienzos de siglo XVIII, se localiza una tercera historia que transcurre, entre finales de 1713 y 1714, en una localidad de la campiña gaditana, en Medina Sidonia. La petición ante el Vicario del inicio de amonestaciones para poder desposarse la realiza Sebastián Baptista, antiguo esclavo, quien, de este modo, nos introduce en el proyecto de vida común de dos jóvenes que se amaban y en los obstáculos que interpone la familia de ella para la celebración de este enlace mixto. Exploradas las voluntades de los novios y amonestados ya, la novia es secuestrada por su tío, maestro boticario de Sanlúcar de Barrameda que, con la aquiescencia de la madre de ésta se la lleva a Sanlúcar. Ella consigue escaparse de casa de su tío y emprende el camino de vuelta hacia Medina, sola y a pie, pero su tío la alcanza y la devuelve a Sanlúcar. Los testigos citados por el Vicario sólo saben dar noticias de cómo ha sucedido el secuestro, nada sobre los sentimientos de la pareja de la que sólo tenemos constancia de su voluntad de contraer matrimonio. En enero de 1714 el arzobispo de Sevilla dicta auto de prisión contra Juan Matheos, el tío de la joven, y orden de liberación de la prometida a fin de que tenga lugar el enlace matrimonial ${ }^{70}$. En ninguno de los estos expedientes, salvo en el tercero y muy discretamente, se habla de amor. Sin embargo, es obvio que estamos en las tres historias ante una épica amorosa. En los tres casos las dificultades de estas parejas para regularizar su situación les han abocado al engaño, la transgresión y la ilegalidad. Salvo en la tercera historia, donde la justicia eclesiástica se pondrá a favor de los novios, las infracciones no quedarán impunes y la restauración del orden legal traerá a la pareja graves consecuencias.

Se podría argumentar que la visualización de las prácticas amorosas sólo a través de los conflictos puede ser una perspectiva forzada y unilateral de la vivencia amorosa. Mi opinión es que, efectivamente, conflictos y contradicciones deben convertirse en el punto nodal del análisis de la cultura amorosa, doblemente instalada -como cultura y como amor- en el diálogo social entre norma y transgresión. Cuando se comenta cómo el teatro barroco está lleno de conductas desviadas, y cómo la novela cortesana también, lógicamente no se quiere decir que en la sociedad barroca están presentes todas estas conductas amorosas desviadas, pero quizá sí que la percepción sobre el amor y su vivencia es la de una realidad llena de conflictos (entre la norma y los deseos). Y no sólo entre la pareja y el orden social que le rodea, como sugieren las tres historias

\footnotetext{
69 Ibidem, L. 3734, exp. 191.

70 AHDC. Varios, L. 337. Expediente de Sebastián Baptista, libertino.
} 
que se presentan aquí, sino también entre los dos miembros de la pareja, sus intereses y el cambio que en ellos puede introducir el tiempo y las circunstancias vitales de cada uno. Un nuevo caso nos sirve para apoyar este extremo y también para introducir una llamada de atención sobre el lenguaje amoroso vertido en documentos íntimos y cómo éste no debe estar al margen de la sospecha del historiador ni de una metodología que prime el contexto. Empecemos esta vez con las palabras, con las grandes palabras de amor que Cristóbal Cuvilla, médico en Cádiz, escribe, en 1738, a su novia Teresa de los Monteros que vive en Sevilla. Si nos detenemos en el análisis de algunos de sus párrafos ${ }^{71}$ : "Hija de mi corazón y de mi vida y de mi alma, es tanto lo que te quiero que si te lo pudiera dar a entender te habías de volver el juicio de contenta...", o "Puedes estar enterada en que te quiero tanto como los desvelos que me cuestas, que como éstos no te los digo te parece que sola tú eres la que quiere...", y "Aunque yo en tu presencia no diga que te quiero mucho no por eso lo creas, ...", lo vemos embarcado en una especie de competición de representación de su amor que responde probablemente a las dudas que su novia le ha manifestado sobre la autenticidad de sus sentimientos. Pero toda la misiva es una suma de figuras propia de la cultura amorosa de la que, sin duda, nuestro protagonista tenía un buen conocimiento:

Sólo tú eres mi cielo, tú la luz de mis ojos, tú mi corazón, tú mi alma, tú no sé que te diga, porque yo quisiera tenerte junto a mi ahora para darte mil abrazos y comerte a bocados. Si no me quisieras me había de volver loco, perdiera el sentido, yo no sé que hiciera porque el considerarlo y estarte escribiendo esto se me está el corazón partiendo. Con que así puedes ver que te quiero, que no te quiero sino que te adoro y quisiera abrirme el corazón (...), que tenerte allí para que ni el sol te ofendiera.

Adiós espejo mío, esposa mía, bien mío, sol mío, diosa mía, hija de mi corazón y de mis potencias, adiós que no puedo todavía apartarme de ti y así quedo rogando a Dios nos de salud y gracia para que se cumplan nuestros gustos y que sea cuanto antes ${ }^{72}$.

Esta es una carta real, que forma parte de un expediente de demanda de esponsales de los que he trabajado y que, más allá de su condición de expresión de los códigos sociales y culturales de su tiempo, constituye un ejemplo claro de cómo el uso de un lenguaje apasionado sólo es indicio de que quien así se expresa sabía lo que había que decir. En este caso, contamos con más cartas y un amplio expediente en el que las cartas son testimonios documentales que presenta la novia como prueba de una palabra de matrimonio que el novio se niega a cumplir. Aunque Teresa ha abandonado su casa materna y se ha dirigido a Cádiz para convencer a Cristóbal de que es tiempo de casarse, tendrá que recurrir a los tribunales para conseguirlo. Es obvio que nuestro protagonista ya no amaba a aquella a quien dirigía esas apasionadas palabras, pero la amó alguna vez? Es aquí donde mi título (Las incertidumbres del corazón) y el propuesto originariamente por Proust para su novela (Las intermitencias del corazón) se reconcilian en una disyuntiva difícil para el historiador.

71 DE LA PASCUA, Ma . J.: "La escritura privada y la representación de las emociones", en BOLUFER, M., BLUTRACHT, C., GOMIS, J. (eds.): Educar los sentimientos y las costumbres. Una mirada desde la historia. Zaragoza, Institución Fernando El Católico-CSIC, 2014, pp. 81-107.

72 Ibidem, p. 100. 